\title{
PENGEMBANGAN MEDIA VIDEO PEMBELAJARAN MERAKIT PERSONAL KOMPUTER
}

\author{
Abdiel Bobi Chahyadi Ginting, Harun Sitompul', Keysar Panjaitan ${ }^{3}$ \\ ${ }^{1}$ Sekolah Menengah Kejuruan SawstaTri Karya, Sumatera Utara \\ ${ }^{2,3}$ Pascasarjana Universitas Negeri Medan \\ abdielbobi@gmail.com ${ }^{l}$
}

\begin{abstract}
Abstrak: Penelitian ini bertujuan untuk (1) Untuk menghasilkan media video pembelajaran perakitan personal komputer yang berkualitas dan layak dijadikan acuan bagi siswa, mudah dipelajari, dipahami dan dapat digunakan secara individual, (2) Untuk mengetahui keefektifan penggunaan media video pembelajaran pada mata pelajaran Produktif Teknik Komputer dan Jaringan pada materi perakitan komputer. Jenis penelitian ini adalah penelitian pengembangan yang menggunakan model pengembangan produk Borg and Gall yang dipadu dengan model desain pembelajaran dari Dick and Carey. Subjek uji coba produk dalam penelitian ini terdiri dari dua ahli materi pelajaran dengan Standar Kompetensi Merakit Personal Komputer, dua ahli desain pembelajaran, dua ahli media pembelajaran, tiga orang peserta didik untuk uji coba perorangan, sembilan peserta didik untuk uji coba kelompok kecil, dan tiga puluh orang peserta didik untuk uji coba lapangan terbatas. Produk akhir dari pengembangan video ini dilanjutkan dengan uji keefektifan produk. Hasil pengujian hipotesis menunjukkan bahwa terdapat perbedaan yang signifikan antara hasil belajar peserta didik yang dibelajarkan menggunakan video dengan hasil belajar peserta didik yang dibelajarkan tanpa menggunakan video. Dari hasil tersebut dapat disimpulkan bahwa hasil belajar peserta didik yang dibelajarkan dengan menggunakan video sebesar $83,66 \%$ lebih tinggi dari pada peserta didik yang dibelajarkan tanpa menggunakan video sebesar $69,46 \%$.
\end{abstract}

Kata Kunci: pengembangan, media video pembelajaran, merakit personal komputer

Abstract: This study aims to (1) To produce quality personal computer learning instructional video media as a reference for students, easy to learn, understand and can be used individually, (2) To determine the effectiveness of the use of instructional video media on Productive subjects Computer and Network Engineering on computer assembly material. This type of research is development research that uses the Borg and Gall product development model combined with a learning design model from Dick and Carey. The product trial subjects in this study consisted of two subject matter experts with Personal Computer Assembling Standards Standards, two learning design experts, two instructional media experts, three students for individual trials, nine students for small group trials, and three twenty students for limited field trials. The final product of the development of this video is followed by a product effectiveness test. Hypothesis testing results indicate that there are significant differences between the learning outcomes of students who are taught using video and learning outcomes of students who are learned without using video. From these results it can be concluded that the learning outcomes of students who were taught using videos amounted to $83.66 \%$ higher than those of students who were learned without using videos of $69.46 \%$.

Keywords: development, learning video media, assembling personal computers

\section{PENDAHULUAN}

Perkembangan TIK juga mengubah paradigma masyarakat dalam mencari dan mendapatkan informasi yang tidak lagi hanya terbatas pada media cetak, radio dan televisi, tetapi juga menjadikan teknologi jaringan global, internet sebagai salah satu sumber informasi utama, sehingga memberikan kemudahan bagi siswa/siswi dalam memperoleh informasi.

Menurut Rusman $(2011,1)$, proses pembelajaran merupakan suatu sistem yang terdiri atas berbagai komponen yang saling berhubungan antara satu sama lainnya.
Komponen tersebut meliputi : tujuan, materi, metode, dan evaluasi. Komponen yang saling mendukung tersebut menimbulkan proses komunikasi melalui proses penyampaian pesan dari sumber pesan melalui saluran atau media tertentu kepada penerima pesan.

Menurut Kunandar (2011: 22), saat ini peran guru sebagai knowledge agent telah bergeser menjadi learning agent yang mendorong, membantu dan mengarahkan peserta didik untuk mengalami proses pembelajaran sesuai dengan minat, bakat, potensi, perkembangan fisik dan psikologinya. 
Dalam proses kegiatan belajar mengajar, guru diharapkan dapat menciptakan kegiatan situasi kegiatan belajar mengajar yang lebih banyak melibatkan aktifitas siswa, sedangkan siswa itu sendiri hendaknya dapat memotivasi dirinya sendiri untuk aktif dalam kegiatan belajar mengajar.

Penggunaan media pembelajaran dalam proses pembelajaran sangat penting, media pembelajaran sangat membantu memecahkan permasalahan belajar dan dapat mempermudah siswa memahami materi pelajaran. Dalam hal ini guru dituntut untuk kreatif. Seperti yang disampaikan Sadiman (2010 : 17), penggunaan media pendidikan secara tepat dan bervariasi dapat mengatasi sikap pasif anak didik. Sesuai dengan pendapat di atas, maka guru dituntut untuk dapat mengembangkan dan menggunakan media pembelajaran.

Senada dengan pendapat Hamalik (dalam Arsyad 2014 : 19) Mengemukakan bahwa pemakaian media pembelajaran dalam proses belajar mengajar dapat membangkitkan keinginan dan minat yang baru, membangkitkan motivasi dan rangsangan keinginan dan minat yang baru, membangkitkan motivasi dan rangsangan kegiatan belajar, dan bahkan membawa pengaruh-pengaruh psikologis terhadap siswa.

Menurut Arsyad (2014: 2) menyatakan bahwa guru dituntut agar mampu menggunakan alat-alat yang dapat disediakan oleh sekolah, dan tidak tertutup kemungkinan bahwa alat-alat tersebut sesuai dengan perkembangan dan tuntutan zaman.

Multimedia bertujuan untuk menyajikan informasi dalam bentuk yang menyenangkan, menarik, mudah dimengerti, dan jelas. Informasi akan mudah dimengerti karena sebanyak mungkin indera, terutama telinga dan mata, digunakan untuk menyerap informasi itu (Arsyad,2010: 170-172).

\section{Hakikat Hasil Belajar Merakit Personal Komputer}

Pada hakikatnya belajar adalah proses perubahan perilaku akibat pengalaman dan latihan, tujuan dari kegiatannya adalah perubahan tingkah laku baik yang menyangkut pengetahuan, keterampilan, maupun sikap, bahkan meliputi segenap organisasi atau pribadi. Belajar merupakan tindakan dan perilaku siswa yang kompleks. Sebagai tindakan, maka belajar hanya dialami oleh siswa sendiri. Siswa merupakan penentu terjadinya proses belajar mengajar, dan lingkungan dijadikan sebagai bahan pelajaran. Sebagaimana dikemukakan Sabri (2005) dalam Musfiqon (2012:3) , belajar adalah proses perubahan perilaku berkat pengalaman dan pelatihan. Artinya tujuan kegiatan belajar ialah perubahan tingkah laku, baik yang menyangkut pengetahuan, keterampilan, sikap, bahkan meliputi segenap aspek pribadi.

Belajar adalah kegiatan yang dilakukan oleh seseorang agar memiliki kompetensi berupa keterampilan dan pengetahuan yang diperlukan. Menurut Gagne (1983 : 49) " $A$ Natural process that leads to changes in what we know, what we can do, and how we behave. Pengertian belajar di atas senada dengan apa yang diungkapkan oleh Kingsley dalam Ahmadi dan Supriono (2008 : 127), Learning is the by which behavior in the broader sense is originated or changed through practice or training. Diartikan belajar adalah proses dimana tingkah laku ( dalam arti luas ) ditimbulkan atau diubah menjadi praktek atau latihan.

Kemandirian dalam menangkap suatu konsep belajar juga berperan dalam mata pelajaran Produktif Teknik Komputer dan Jaringan pada materi perakitan personal komputer, dengan belajar mandiri siswa dapat mempelajari pokok bahasan atau topik pelajaran tertentu dengan melihat dan mendengarkan program media baik berupa visual, audio maupun audio visual tanpa bantuan atau terbatas dari orang lain Senada dengan pendapat Wedemeyer (dalam Srililis 2008: 5) Kemandirian dalam belajar perlu diberikan kepada peserta didik supaya mereka mempunyai tanggung jawab dalam mengatur dan mendisiplinkan dirinya dan dalam mengembangkan kemampuan belajar atas kemauan sendiri.

Hakikat hasil belajar merupakan tindakan dan perilaku siswa yang kompleks. Siswa merupakan bagian dari faktor penentu terjadinya proses pembelajaran yang efektif dan efisien. Aktifitas belajar siswa merupakan bagian dorongan dari rasa keingintahuan dan merupakan kebutuhan saat itu. Reigeluth (1983: 25) secara umum mengkategorikan indikator keberhasilan siswa dalam belajar terdiri dari tiga hal yaitu : (1) efektifitas pembelajaran (effectiveness), yang biasanya diukur dari tingkat keberhasilan siswa dalam berbagai hal, (2) efisiensi pembelajaran (efficiency), yang biasanya diukur dari waktu dan pembiayaan, dan (3) daya tarik 
pembelajaran (appeal), yang biasanya dari tendensi siswa untuk belajar terus menerus. Dengan mengacu pada uraian tersebut dapat disimpulkan bahwa keberhasilan suatu kegiatan pembelajaran dapat dilihar melalui tiga hal, yaitu efektifitas, efisiensi dan daya tarik.

\section{Hakikat Teknologi Pembelajaran}

Teknologi Pendidikan muncul sebagai upaya untuk memecahkan permasalahan dalam belajar. Dengan menerapkan teori dan praktik dari ilmu Teknologi Pendidikan dapat diatasi apa yang menjadi masalah dalam belajar. AECT (Association of Educational Communications Technology) dalam Miarso, 2009: 139) Mendefinisikan, “ Teknologi Pendidikan sebagai berikut: Teknologi pendidikan adalah proses kompleks dan terpadu yang melibatkan orang-orang, prosedur, ide, peralatan, dan organisasi untuk menganalisis mesalah, mencari jalan pemecahan, melaksanakan, mengevaluasi, mengelola pemecahan masalah yang menyangkut semua aspek belajar manusia".

Menurut Miarso (2009: 167-168) "Teknologi pendidikan berusaha memecahkan dan memfasilitas pemecahan masalah belajar pada manusia sepanjang hayat di mana saja, kapan saja, dengan apa saja, dan oleh siapa saja. Miarso (2009: 168) Menyebutkan "empat komponen dalam teknologi pembelajaran (1) teori praktek, (2) desain, pengembangan, pemanfaatan, pengelolaan, penilaian, dan penelitian, (3) proses, sumber dan sistem, (4) untuk belajar. Dalam definisi Seels dan Richey tersebut terdapat enam kawasan teknologi pendidikan/pembelajaran, yaitu desain, pengembangan, pemanfaatan, pengelolaan, penilaian dan penelitian proses, sumber, dan sistem belajar."

Menurut Anglin (1995) teknologi pendidikan adalah kombinasi dari pembelajaran, belajar pengembangan, pengelolaan , dan teknologi lain yang diterapkan untuk memecahkan masalah pendidikan. Definisi ini memandang teknologi pendidikan sebagai salah satu cabang dari disiplin ilmu pendidikan yang berkembang sejalan dengan perkembangan teknologi, semenjak itulah lahir disiplin teknologi pendidikan. Sedangkan Hackbarth (1996: 10) teknologi pendidikan adalah konsep multi dimensional yang meliputi: (1) suatu proses sistematis yang melibatkan penerapan pengetahuan dalam upaya mencari solusi yang dapat digunakan dalam memecahkan masalahmasalah belajar dan pembelajaran, (2) produk seperti buku teks, program audio, program televisi, software komputer, dan lain-lain, (3) suatu profesi yang terdiri dari berbagai kategori pekerjaan, dan (4) merupakan bagian spesifik dari pendidikan.

Berdasarkan definisi ini teknologi pendidikan mempunya dua bidang kajian utama, yaitu : (a) mengkaji tentang teori belajar dan perilaku manusia lainnya (soft technology), dan (b) mengkaji teknologi terapan yang diaplikasikan untuk memecahkan masalah pembelajaran (hard technology). Namun, fokus dari teknologi pembelajaran bukan pada proses psikologis bagaimana peserta didik belajar, melainkan pada proses psikologis bagaimana peserta didik belajar, bagaimana teknologi perangkat lunak dan keras digunakan mengkomunikasikan pengetahuan, keterampilan, atau sikap kepada peserta didik sehingga peserta didik mengalami perubahan perilaku seperti yang diharapkan (Suparman, 2004:30).

Dalam teknologi pembelajaran baik teori maupun praktek, banyak menggunakan model. Model procedural, yang menguraikan cara pelaksanaan tugas membantu menghubungkan teori dan praktek. Teori juga dapat menghasilkan model untuk memvisualisasikan hubungan; model ini disebut juga model konseptual Seels \& Richey (2000:10-12).

\section{Hakikat Media pembelajaran video Perakitan Personal Komputer.}

Kata media berasal dari bahasa Latin medius yang secara harafiah berarti tengah, perantara, atau pengantar. Dalam bahasa arab, media adalah perantara atau pengantar pesan dari pengirim kepada penerima pesan menurut Arsyad (2014:3). Sadiman (2005:6) mengemukakan media adalah perantara atau pengantar pesan dari pengirim ke penerima pesan. Dalam bahasa arab, media juga berarti perantara (warsail) atau pengantar pesan dari pengirim kepada penerima pesan (Arsyad, 2006:3).

Menurut Hamalik (2005:125), media sebagai teknik yang digunakan dalam rangka lebih mengefektifkan komunikasi antara guru dan murid dalam proses pendidikan dan pembelajaran disekolah. Senada dengan pendapat diatas menurut Miarso (1986 :47) mengartikan media sebagai wadah dari pesan yang oleh sumber atau penyalurnya ingin 
diteruskan kepada sasaran atau penerima pesan tersebut, materi yang ingin disampaikan adalah pesan pembelajaran dan bahwa tujuan yang ingin dicapai adalah terjadinya proses belajar.

Menurut Santyasa (dalam Sahid, 2012), proses pembelajaran mengandung lima komponen komunikasi, yakni guru (komunikator), bahan pembelajaran, media pembelajaran, siswa (komunikan), dan tujuan pembelajaran. Senada dengan pendapat di atas menurut Hamalik (dalam Arsyad,2014), di mana ia melihat bahwa hubungan komunikasi akan lancar dengan hasil yang maksimal apabila menggunakan alat bantu yang disebut komunikasi.

Dari hasil penelitian yang dilakukan oleh Agung Bakti Saputra (2011), media video pembelajaran sangat menunjang pembelajaran. Maka dari itu peneliti mencoba membangun suasana belajar mengajar yang efektif, komunikatif, interaktif dengan pengembangan media pembelajaran dalam penelitian ini peneliti mengembangkan media video pembelajaran perakitan personal komputer.

Desain pembelajaran juga merupakan prinsip-prinsip penerjemah dar pembelajaran dan instruksi ke dalam rencana-rencana untuk bahan-bahan dan aktivitas-aktivitas instruksional (Smith and Regan, 1993).

Arsyad (2011 :49) menyatakan bahwa video merupakan gambar dalam frame, di mana frame demi frame diproyeksikan melalui lensa proyektor secara mekanis sehingga pada layar terlihat gambar hidup. Dari pengertian di atas dapat disimpulkan, bahwa video merupakan salah satu jenis media audio-visual yang dapat menggambarkan suatu objek yang bergerak bersama-sama dengan suara alamiah atau suara yang sesuai. Kemampuan video melukiskan gambar hidup dan suara memberikan daya tarik sendiri. Video dapat menyajikan informasi, memaparkan proses, menjelaskan konsepkonsep yang rumit, mengajarkan keterampilan, menyingkat atau memperpanjang waktu, dan mempengaruhi sikap.

Hakikat Pengembangan Media video
pembelajaran Perakitan Personal Komputer. Pengembangan dalam bahasa inggris disebut development, dalam bahasa Jerman disebut durchfuhrung, mempunyai makna : pertama, pengelolaan frase-frase dan motifmotif dengan detail terhadap tema atau yang dikemukakan sebelumnya, kedua; suatu bagian dari karangan yang memperluas, memperdalam dan menguatkan argumentasi yang terdapat dalam bagian eksposisi, Komaruddin,dkk (2000:186).

Miarso (2004:419) mengemukakan bahwa bila dikaji secara empiris, pengembangan adalah cara yang dilakukan dengan menciptakan sesuatu model terbatas yang diawasi secara cermat terlebih berbagai komponen pengembangan dicobakan, dinilai dan disempurnakan.

Menurut Borg \& Gall (1983: 772) pengertan penelitian pengembangan sebagai berikut: "Educational Research and Development $(R \& D)$ is a prosess used to develop and validate educational products". Penelitian pendidikan dan pengembangan (R \& D) adalah proses yang digunakan untuk mengembangkan dan memvalidasi produk pendidikan. Sejalan dengan pendapat diatas Seels dan Richey (1994:38-39) menyatakan bahwa hasil dari pengembangan adalah terciptanya suatu produk dalam bentuk fisik. Slah satu penggerak dari kawasan pengembangan adalah adanya manifestasi disik dari teknologi yang berupa perangkat lunak (Software) dan bahan pembelajaran. Sugiyono (2012: 297) menyatakan bahwa penelitian dan pengembangan atau Research and Development adalah metode penelitian yang digunakan untuk menghasilkan produk tertentu, dan menguji keefektifan produk.

Model pengembangan pembelajaran berfungsi mengarahkan kita dalam mendesain pembelajaran yang dapat kita gunakan sebagai pedoman dalam pembelajaran guna mencapai pembelajaran efektif, efisien, berdaya guna, menarik dan humanis. Senada dengan hal tersebut model pembelajaran Dick \& Carey (2015:5) adalah salah satu contoh model pengembangan yang berorientasi pada hasil, karena penerapan konsep-konsep dan prinsipprinsip perancangannya akan menghasilkan bahan belajar mandiri. Pengembangan model Dick \& Carey dapat dilihat pada Gambar 1 berikut ini : 


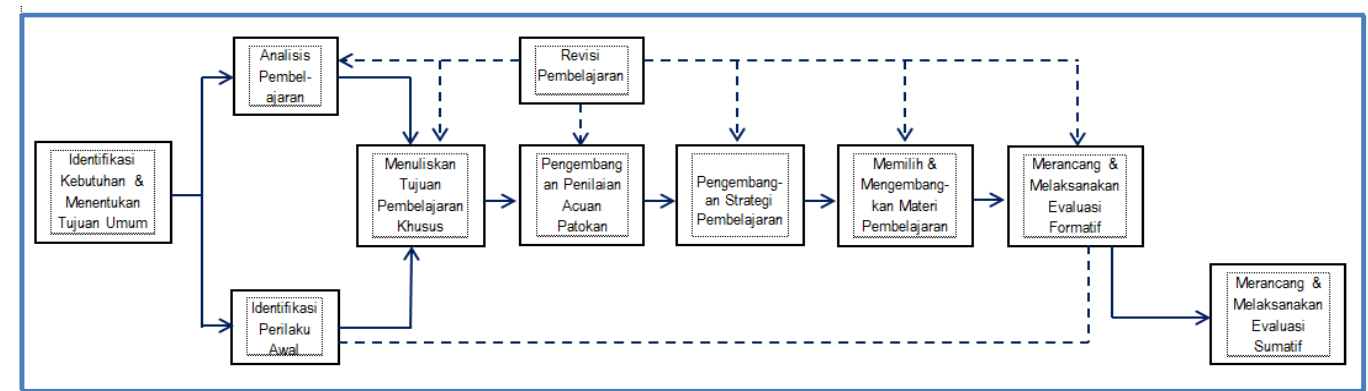

Gambar 1. Pengembangan Model Dick \& Carey

Dari tahapan pengembangan di atas, pengembangan yang akan dieksploitasikan di sini berupa video pembelajaran dimana media sendiri memiliki arti yang beragam. Smaldino dkk (2005:17) video adalah sebagai media penyimpanan pesan, termasuk media audiovisual atau media pandang dengar. Senada dengan pendapat Sanaky (2009 : 102) mengatakan bahwa media video adalah seperangkat alat yang dapat memproyeksikan gambar bergerak. Dari pendapat di atas penulis menyimpulkan bahwa media video merupakan salah satu alat yang digunakan sebagai perantara atau pengantar pesan dari pengirim ke penerima pesan dalam pembelajaran yang mana media video sendiri adalah segala sesuatu yang menyangkut bahan (software) dan perangkat keras/alat (hardware), yaitu sesuatu benda yang dapat dilihat, didengar, atau diraba dengan pancaindera, penekanan media video pembelajaran terdapat pada visual dan audio yang dapat digunakan untuk menyampaikan isi materi ajar dari sumber belajar ke pembelajar ( individu atau kelompok), yang dapat merangsang pikiran, perasaan, perhatian, minat pebelajar, dapat menangkap, memproses, dan menyusun kembali informasi visual atau verbal sedemikian rupa sehingga proses belajar ( di dalam/di luar kelas) menjadi lebih efektif. Daryanto ( $2010: 88$ ) menyatakan kemampuan video dalam memvisualisasikan materi sangat efektif untuk membantu dalam menyampaikan materi yang bersifat dinamis terutama materi yang memerlukan visualisasi yang mendemonstrasikan. Dari penjelasan tersebut maka materi merakit komputer merupakan mata pelajaran yang sebagian materinya banyak melakukan demonstrasi, sehingga tepat alasan penulis untuk mengemas materi pelajaran merakit personal komputer dengan media video pembelajaran.

Berdasarkan latar belakang masalah, identifikasi masalah dan pembatasan masalah yang telah dikemukakan di atas, maka masalah penelitian ini adalah; (1) Apakah video pembelajaran yang dikembangkan pada mata pelajaran Produktif Teknik Komputer dan Jaringan materi perakitan personal komputer layak digunakan; (2) Apakah video pembelajaran perakitan personal komputer ini efektif dibelajarkan?

\section{METODE}

Penelitian ini dilaksanakan di SMK Swasta Tri Karya jurusan Teknik Komputer dan Jaringan . Dalam penelitian dan pengembangan ini menggunakan metode pengembangan penelitian mengacu kepada Research and Development (R \& D) dari model Borg \& Gall (1983) yang memiliki tujuan untuk mengembangkan dan memvalidasi produk dengan perencanaan dalam pengembangan video pembelajaran Dick \& Carey.

Secara konseptual, pendekatan penelitian dan pengembangan mencakup 10 langkah umum, sebagaimana diuraikan Borg \& Gall (1983:775), seperti Gambar di bawah ini:

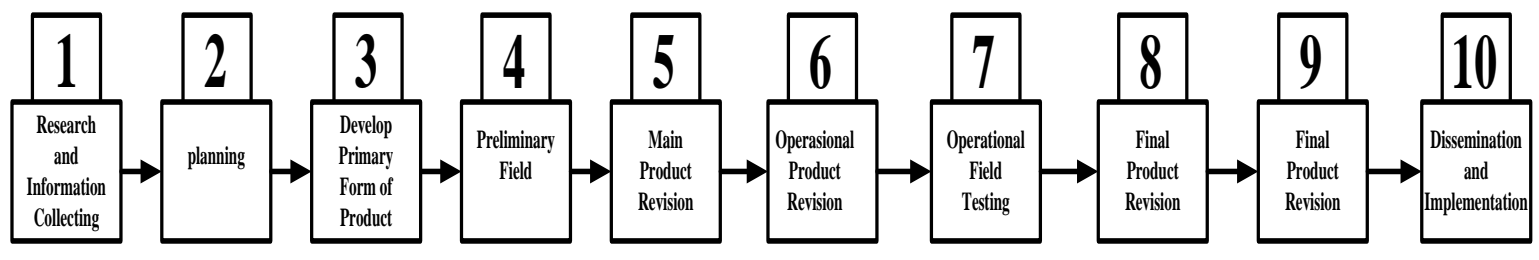

Gambar 2. Skema prosedur pengembangan hasil adaptasi dari prosedur pengembangan Borg \& Gall (Sumber : Borg\&Gall, 1983:775) 


\section{Prosedur Pengembangan}

Prosedur pengembangan media video pembelajaran ini dilakukan dengan prosedur sebagai berikut :

1. Mengembangkan desain pembelajaran. Adapun langkah pengembangan desain pembelajarannya

2. Pembuatan desain video pembelajaran yang akan dikembangkan dalam media video pembelajaran, yang meliputi: (a) pembuatan flowchart, (b) pembuatan storyboard, (c) pembuatan naskah.

3. Pengumpulan bahan, yang meliputi: (a) pembuatan dan pengumpulan gambar (image), merekam suara, membuat animasi-animasi yang akan digunakan dalam materi maupun simulasi, (b) perekaman dan pengumpulan audio.

Mengembangkan bentuk awal produk dengan menggunakan program Aplikasi : Camtasia, Cyberlink Power DVD Ultra v8.0, Picasa, Ulead Video Studio 11.5, Adobe Premiere Element 8.

4. Melakukan validasi produk dari ahli media dan ahli materi

5. Melakukan revisi tahap pertama hasil dari validasi ahli media, dan ahli materi

6. Melakukan revisi produk tahap awal

7. Melakukan uji coba perorangan dengan siswa calon pengguna media pembelajaran;.

8. Melakukan revisi tahap ke dua

9. Melakukan uji coba lapangan

Analisis data dalam penelitian ini menggunakan analisis deskriptif kuantitatif, semua data yang terkumpul dianalisa dengan teknik statistik deskriptif yang secara kuantitatif dipisahkan menurut kategori untuk mempertajam penilaian dalam menarik kesimpulan. Data kualitatif yang berupa pernyataan sangat kurang baik, cukup, sedang dan sangat baik diubah menjadi data kuantitatif dengan skala nilai 1 sampai 5. Hasilnya dibagi rata-rata dan digunakan untuk menilai kualitas media video pembelajaran. Kriteria media video akan dikonversikan menjadi nilai dengan skala lima menggunakan skala Likert yang dianalisis secara deskriptif persentase dengan rumusan sebagai berikut Sugiyono (2007):

Skor Empiris $=\frac{\text { jumlah skor yang diperoleh }}{\text { jumlah skor ideal seluruh } \text { item }} \times 100 \%$

Kemudian untuk menguji hipotesis kedua yakni mengenai keefektifitasan media video pembelajaran dilakukan eksperimen dengan menggunakan uji t. Adapun menurut Sudjana (2009:367) mengungkapkan ada dua teknik analisis data yang dapat dilakukan yaitu statistik deskriptif dan statistik inferensial. Analisis data dalam penelitian ini menggunakan analisis kuantitatif. Adapun langkah-langkah analisis yang harus dilakukan adalah sebagai berikut:

\section{Statistik Deskriptif}

Statistik deskriptif yang digunakan untuk menggambarkan data yang terkumpul dan bukan mengambil keputusan, statistik ini antara lain dengan melakukan penggambaran dengan tabel, grafik, atau diagram serta perhitungan mean, modus median, dan standar deviasi.

Mean adalah rata-rata dari nilai yag diperoleh dengan menggunakan rumus:

$$
\text { Mean }=\frac{2 x_{t}}{n}
$$

Modus adalah fenomena yang paling banyak terjadi. Jika data telah disusun dalam daftar distribusi frekuensi rumus untuk mencari modus adalah:

Mo $=$ Modus

b = Batas bawah kelas modal, kelas

interval dengan frekuensi terbanyak

$\mathrm{p} \quad=$ Panjang kelas

$\mathrm{b}_{1} \quad=$ frekuensi kelas modal dikurangi

frekuensi kelas sebelumnya

$\mathrm{b}_{2} \quad=$ frekuensi kelas modal dikurangi

frekuensi kelas sesudahnya

Median adalah data tengah dan untuk mencarinya menggunakan rumus:

$$
\mathbf{M e}=\mathbf{b}+\mathbf{p} \frac{0,5 n-F}{f}
$$

$\mathrm{Me} \quad=$ Median

$\mathrm{b} \quad=$ Batas bawah kelas median

$\mathrm{p} \quad=$ Panjang kelas median

$\mathrm{n} \quad=$ Banyak data

$\mathrm{F} \quad=$ Jumlah frekuensi samapai kelas

diatas kelas median

$\mathrm{f} \quad=$ Frekuensi kelas median

Rumus untuk mencari Standar Deviasi

adalah

$$
\text { SD }=\sqrt{\frac{n \sum X^{2}-\left(\sum x\right)}{n(n-1)}}
$$

Statistik deskriptif digunakan pada tahap pengembangan, mulai analisis kebutuhan sampai dengan uji coba. 
2. Statistik Inferensial

Statistik inferensial digunakan untuk menguji hipotesis yang telah diajukan. Sebelum dilakukan uji keefektifan perlu dilakukan uji normalitas, uji homogenitas. Uji normalitas dilakukan untuk mengetahui apakah data berdistribusi normal. Uji homogenitas untuk mengetahui apakah data homogen dengan mengetahui sama tidaknya varians dua buah distribusi atau lebih.

Uji Normalitas data yang di uji dengan uji Lilliefors, dengan prosedur:

1) Mencari rata-rata dan simpangan baku dari data yang ada

2) Mencari bilangan baku $z$ dengan rumus $z_{1}=$ $\frac{X_{i}-\overline{\mathrm{X}}}{\mathrm{s}}$

3) Dihitung peluang $\mathrm{F}(\mathrm{zi})=\mathrm{P}(\mathrm{z} \leq \mathrm{zi})$

4) Di hitung proporsi $S(z i)$ dengan rumus $S$ $(\mathrm{zi})=\frac{\text { Banyaknya } Z_{\text {yang }} \leq \mathrm{zi}}{n}$

5) Dihitung harga mutlak dari $\mathrm{F}(\mathrm{zi})-\mathrm{S}(\mathrm{zi})=$ [(zi) - S(zi) ]

6) Dicari [(zi) - S(zi) ] yang paling besar $L_{h}$

7) Uji Hipotesis yaitu $\mathrm{H}_{0}=\mathrm{L}_{\mathrm{h}} \geq \mathrm{L}_{\mathrm{t}}$ artinya data distribusi tidak normal dan jika $\mathrm{H}_{\mathrm{a}}=\mathrm{L}_{\mathrm{h}} \leq$ $\mathrm{L}_{\mathrm{t}}$ artinya data distribusi normal

Uji Homogenitas dilakukan dengan Uji

$\mathrm{F}$ (Fisher) dengan menggunakan varians ke dua data, dengan prosedur

1) Mencari masing-masing data

2) Mencari $F_{h}$ dengan rumus $F_{h}=$ varians terbesar varians terkecil

3) Mencari $F_{t}$ dengan varians terbesar adalah $\mathrm{dk}$ pembilang $\mathrm{n}-1$, dan untu varians terkesil $\mathrm{dk}$ penyebut $\mathrm{n}-1$

4) Menentukan homogenitas dengan pedoman jika $F_{h}<F_{t}$ data Homogen, jika $F_{h}>F_{t}$ berarti data Tidak Homogen

Uji Keefektifan dilakukan untuk melihat perbedaan yang signifikan antara hasil belajar dengan menggunakan multimedia interaktif dan media grafis dengan uji beda (uji t)

$$
\mathbf{t}=\frac{\bar{X}_{1}-\bar{X}_{2}}{s \sqrt{\frac{1}{n_{1}}+\frac{1}{n_{2}}}}
$$

dimana $\mathrm{S}$ adalah Varians gabungan yang dihitung dengan rumus :

$$
S^{2}=\frac{\left(n_{1}-1\right) S_{1}^{2}+\left(n_{1}-1\right) S_{2}^{2}}{n_{1}+n_{2}-2}
$$

Dimana

$\mathrm{t}=$ Distribusi $t$

$\bar{X}_{1}=$ Rata - rata siswa yang menggunakan Media Video
$\bar{X}_{2}=$ Rata - rata siswa yang menggunakan pembelajaran konvensional $n_{1}=$ Jumlah siswa yang menggunakan Media Video $n_{2}=$ Jumlah siswa yang menggunakan pembelajaran konvensional $S=$ Varians gabungan

$S_{1}=$ Simpangan baku siswa yang menggunakan Media Video $S_{2}=$ Simpangan baku siswa yang den gan pembelajaran konvensional

Dengan $\mathrm{dk}=\left(n_{1}+n_{2}-2\right)$, kriteria

korelasi yang diperoleh dikatakan signifikan (hipotesis diterima) jika $T_{\text {hitung }}>T_{\text {tabel }}$ untuk taraf signifikan 0,05. Untuk melihat keefektifan multimedia interaktif yang di experimenkan digunakan rumus perhitungan efeektifitas berikut (Sudiyono, 2009)

Efektifitas $=\frac{\text { JumlahSkor yang diperoleh }}{\text { Jumlah skor ideal seluruh item }} \times 100 \%$

\section{HASIL DAN PEMBAHASAN \\ Data Hasil Uji Coba Perorangan}

Uji coba lapangan terbatas pada 30 orang peserta didik guna menghasilkan data-data yang akan dipergunakan untuk mengetahui bagaimana manfaat media video pembelajaran merakit personal komputer pada pelajaran produktif Teknik Komputer Dan Jaringan bagi pemakainya dan uji coba lapangan menghasilkan data-data yang nantinya akan mengukur efektifitas dari produk yang dikembangkan.

Penilaian yang dilakukan pada uji coba lapangan terbatas terhadap media media video pembelajaran merakit personal komputer yang telah dikembangkan secara keseluruhan termasuk dalam kriteria "sangat baik" untuk seluruh indikator penilaian dengan persentase skor total $97,17 \%$.

\section{Analisis Data}

Hasil penilaian oleh ahli materi, ahli desain pembelajaran, dan ahli media pembelajaran pada setiap aspek penilaian secara keseluruhan ditentukan oleh skor rata-rata pada kategorinya masing-masing. Hasil penilaian tersebut kemudian dianalisis untuk menentukan layak tidaknya media video pembelajaran merakit personal komputer yang dikembangkan. Berikut persentase rata-rata dari hasil penilaian dari ahli materi, ahli desain, dan ahli media pembelajaran akan dibahas sebagai berikut.

\section{Analisi Data Penilaian Ahli Materi}

Ahli materi menilai media video tutorial merakit personal komputer berdasarkan empat Aspek yaitu : kelayakan isi, penyajian, kebahasaan, kegrafikan. Persentase rata-rata hasil penilaian dari hasil penelitian ahli materi 
terhadap media video pembelajaran yang dikembangkan terlihat pada Tabel 1 berikut ini.

Tabel 1. Persentase Rata-rata Hasil Penilaian Ahli Materi Terhadap Media Video Tutorial Merakit Personal Komputer oleh Ahli Materi

\begin{tabular}{|l|l|c|c|}
\hline No & Indikator Penilaian & Persentase Rata-rata & Kriteria \\
\hline 1 & Aspek Kelayakan Isi & $92,00 \%$ & Sangat Baik \\
\hline 2 & Aspek Penyajian & $93,75 \%$ & Sangat Baik \\
\hline 3 & Aspek Kebahasaan & $93.33 \%$ & Sangat Baik \\
\hline 4 & Aspek Kegrafikan & $90,00 \%$ & Sangat Baik \\
\hline & Rata-rata & $\mathbf{9 2 , 2 7 \%}$ & Sangat Baik \\
\hline
\end{tabular}

\begin{abstract}
Analisis Data Penilaian Ahli Desain isi, aspek penyajian pembelajaran, aspek Pembelajaran kebahasaan. Adapun persentase rata-rata dari Berdasarkan penialaian ahli desain hasil penilaian ahli desain pembelajaran pembelajaran terhadap media video terhadap media video pembelajaran yang telah pembelajaran merakit personal komputer yang dikembangkan dapat dilihat pada Tabel 2 dikembangkan telah memiliki kelayakan berikut
\end{abstract} berdasarkan tiga aspek yaitu aspek kelayakan ini.

Tabel 2. Persentase Rata-rata Hasil Penilaian Ahli Desain Pembelajaran terhadap Media Video pembelajaran Merakit Personal Komputer

\begin{tabular}{|c|l|c|c|}
\hline No & \multicolumn{1}{|c|}{ Kategori } & Persentase Rata-rata & Kriteria \\
\hline 1 & Aspek Kelayakan Isi & $95,00 \%$ & Sangat Baik \\
\hline 2 & Penyajian Pembelajaran & $92,73 \%$ & Sangat Baik \\
\hline 3 & Kebahasaan & $92,86 \%$ & Sangat Baik \\
\hline \multicolumn{2}{|c|}{ Rata-rata } & $\mathbf{9 3 , 5 3 \%}$ & Sangat Baik \\
\hline
\end{tabular}

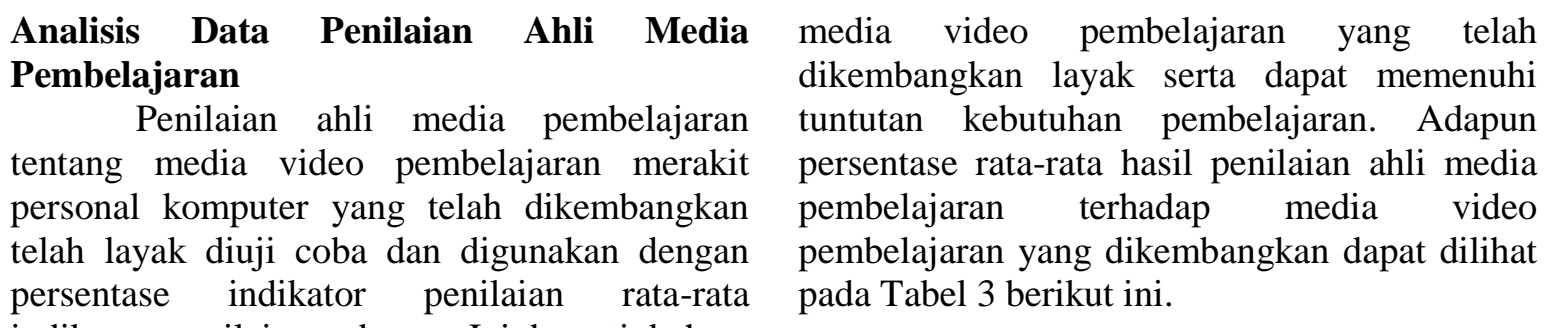
indikator penilaian sebesar. Ini berarti bahwa

Tabel 3. Persentase Rata-rata Hasil Penilaian Ahli Media Pembelajaran terhadap Media Video pembelajaran Merakit Personal Komputer

\begin{tabular}{|c|c|c|c|}
\hline No & Kategori & Persentase Rata-rata & Kriteria \\
\hline 1 & Aspek Pemrograman & $92,00 \%$ & Sangat Baik \\
\hline 2 & Kualitas Teks dan Tampilan & $93,33 \%$ & Sangat Baik \\
\hline \multicolumn{2}{|c|}{ Rata-rata } & $\mathbf{9 2 , 6 7 \%}$ & Sangat Baik \\
\hline
\end{tabular}

\section{Analisis Data Hasil Uji Coba Perorangan}

Setelah melewati tahapan validasi para ahli, selanjutnya dilakukan uji coba perorangan untuk mengetahui persepsi peserta didik sebagai pengguna sebelum dilakukannya uji coba kelompok kecil terhadap media video tutorial merakit personal komputer yang dikembangkan. Hasil analisa data uji coba perorangan pada setiap aspek penilaian secara keseluruhan ditentukan oleh skor rata-rata pada kategorinya masing-masing. Hasil penilaian menunjukkan kriteria dengan "sangat baik" dengan persentase rata-rata $89,58 \%$. Penilaian ini terdiri dari beberapa kategori indikator penilaian yaitu aspek tampilan, penyajian materi pembelajaran, serta manfaat. Persentase persepsi peserta didik pada uji coba perorangan dapat dilihat pada Tabel 4 berikut ini. 
Tabel 4. Persentase Perorangan Skor Uji Coba Perorangan Terhadap Media Video pembelajaran Merakit Personal Komputer

\begin{tabular}{|l|l|c|c|}
\hline No & Kategori & Persentase Rata-rata & Kriteria \\
\hline 1 & Aspek Kualitas Materi Pembelajaran & $89,17 \%$ & Sangat Baik \\
\hline 2 & Aspek Teknis / Tampilan & $90,00 \%$ & Sangat Baik \\
\hline Rata-rata & $\mathbf{8 9 , 5 8 \%}$ & Sangat Baik \\
\hline
\end{tabular}

\section{Analisis Data Hasil Uji Coba Kelompok Kecil}

Hasil analisis dapat pada uji coba kelompok kecil pada setiap aspek penilaian akan diuraikan pada tabel 5 sebagai berikut :

Tabel 5. Persentase Perolehan Skor Uji Coba Kelompok Kecil Terhadap Media Video pembelajaran Merakit Personal Komputer

\begin{tabular}{|l|l|c|c|}
\hline No & Kategori & Persentase Rata-rata & Kriteria \\
\hline 1 & Aspek Kulitas Materi Pembelajaran & $92,22 \%$ & Sangat Baik \\
\hline 2 & Aspek Teknis / Tampilan & $90,00 \%$ & Sangat Baik \\
\hline \multicolumn{2}{|c|}{ Rata-rata } & $\mathbf{9 1 , 1 1 \%}$ & Sangat Baik \\
\hline
\end{tabular}

Tabel 5 menunjukkan persentase ratarata hasil penilaian pada uji coba kelompok kecil pada peserta didik kelas X Teknik Komputer Dan Jaringan terhadap aspek kualitas materi pembelajaran sebesar 92,22\% termasuk dalam kategori sangat baik serta layak digunakan, skor persentase pada aspek teknis / tampilan sebesar $90,00 \%$ termasuk dalam kategori sangat baik. Secara keseluruhan aspek tersebut dalam kategori "sangat baik" dengan skor persentase rata-rata $91,11 \%$ serta layak dimanfaatkan untuk kebutuhan pembelajaran.

\section{Analisis Data Hasil Uji Coba Lapangan Terbatas}

Uji coba lapangan terbatas dilakukan pada 30 orang peserta didik untuk mendapatkan informasi mengenai lanjutan keterpakaian media video pembelajaran untuk pemakai yang lebih banyak. Penilaian yang dilakukan pada uji coba ini mendapat kriteria dengan "sangat baik" dengan persentase rata-rata $97,25 \%$. Untuk rincian penilaiannya dapat dilihat pada Tabel 6 berikut

Tabel 6. Persentase Perolehan Skor Uji Coba Lapangan Terbatas Terhadap Media Video pembelajaran Merakit Personal Komputer

\begin{tabular}{|c|c|c|c|}
\hline No & Kategori & Persentase Rata-rata & Kriteria \\
\hline 1 & Aspek Kualitas Materi & $97,17 \%$ & Sangat Baik \\
\hline 2 & Aspek Teknis / Tampilan & $97,33 \%$ & Sangat Baik \\
\hline \multicolumn{2}{|c|}{ Rata-rata } & $\mathbf{9 7 , 2 5 \%}$ & Sangat Baik \\
\hline
\end{tabular}

Hasil Penelitian Uji Coba Efektifitas Produk Hasil Belajar Tanpa Menggunakan Media Video pembelajaran Merakit Personal Komputer Pada Siswa Berdasarkan data yang diperoleh dapat diketahui bahwa skor hasil belajar produktif Teknik Komputer Dan Jaringan pada topik merakit personal komputer tanpa menggunakan video pembelajaran merakit personal komputer diperoleh skor terendah 60 dan skor tertinggi 89, rata-rata skor 69,46 modus 76,81, median 70,45 dan simpangan baku 5,24. untuk melihat skor peserta didik digunakan kelas interval yaitu skor antar frekuensi absolute yaitu jumlah peserta didik yang memiliki skor hasil belajar, dan frekuensi relatif yaitu jumlah persen skor hasil belajar.

\section{Pengujian Persyaratan Analisis Data}

Uji persyaratan analisis data dilakukan untuk menentukan uji statistik parametrik hipotesis penelitian. Pengujian analisis data dilakukan dengan menguji normalitas data penelitian dengan uji Liliefors. Rangkuman uji normalitas data dengan uji Liliefors adalah sebagai berikut pada Tabel 7 . 
Tabel 7. Rangkuman Uji Normalitas Data dengan Uji Liliefors

\begin{tabular}{|l|l|l|l|l|l|}
\hline No. & \multicolumn{1}{|c|}{ Data } & \multicolumn{1}{|c|}{ Kelas } & \multicolumn{1}{|c|}{$\mathbf{L}_{\text {hitung }}$} & $\mathbf{L}_{\text {tabel }}$ & Kesimpulan \\
\hline 1. & Postes & Eksperimen & 0,159 & 0,161 & Normal \\
\hline 2. & Postes & Kontrol & 0,125 & 0,161 & Normal \\
\hline
\end{tabular}

Sedangkan untuk menguji homogenitas data penelitian digunakan uji F. Rangkuman uji homogenitas data dengan uji Fisher sebagai berikut pada Tabel 8.

Tabel 8. Rangkuman Uji Homogenitas Data Penelitian

\begin{tabular}{|l|l|l|c|c|c|}
\hline No. & \multicolumn{1}{|c|}{ Data } & \multicolumn{1}{|c|}{ Kelas } & $\mathbf{F}_{\text {hitung }}$ & $\mathbf{F}_{\text {tabel }}$ & Kesimpulan \\
\cline { 1 - 3 } 1. & Postes & Eksperimen & \multirow{2}{*}{1,20} & 1,77 & \multirow{2}{*}{ Homogen } \\
\hline 2. & Postes & Kontrol & & \\
\hline
\end{tabular}

$$
\begin{aligned}
& \text { Uji t Postes } \\
& \mathrm{H}_{0}: \mu_{1}=\mu_{2} \\
& \mathrm{H}_{0}: \mu_{1}>\mu_{2}
\end{aligned}
$$

Keterangan :

$\mu_{1}$ : rata-rata hasil belajar speserta didik yang diajarkan menggunakan media video pembelajaran

$\mu_{2}$ : rata-rata hasil belajar peserta didik yang diajarkan tanpa menggunakan media video pembelajaran

$\mathrm{H}_{1}$ : tidak ada perbedaan hasil belajar Media Video pembelajaran yang diajarkan menggunakan media video pembelajaran lebih tinggi dari peserta didik yang diajar dengan pembelajaran tanpa menggunakan media video pembelajaran.

$\mathrm{H}_{2}$ : ada perbedaan hasil belajar merakit personal komputer yang diajar menggunakan media video pembelajaran tanpa menggunakan media video pembelajaran.

Setelah dilakukan uji t postes menggunakan uji t. Hal ini dilakukan untuk mengetahui hipotesis dengan menggunakan uji t. Hal ini dilakukan untuk mengetahui apakah ada perbedaan hasil belajar peserta didik setelah dilakukan perlakuan yang berbeda.

Berdasarkan data pada Tabel 4.23 dan Tabel $4.24 \mathrm{di}$ atas maka dapat disimpulkan bahwa data penelitian telah memenuhi persyaratan untuk dilakukan pengujian hipotesis.

Hipotesis yang diujikan pada penelitian ini adalah terdapat perbedaan yang signifikan antara hasil belajar peserta didik yang dibelajarkan menggunakan media video dan hasil belajar peserta didik yang tidak menggunakan media video. Pengujian hipotesis yang digunakan adalah uji-T. Dari perhitunganperhitungan diperoleh output $t_{\text {hitung }}$ sebesar 8,77 dan $t_{\text {tabel }}$ sebesar 1,99. Maka diperoleh bahwa $\mathrm{t}_{\text {hitung }}>\mathrm{t}_{\text {tabel }}$ atau $8,77<1,99$ atau dengan kata lain Ho ditolak dan Ha diterima.

Berdasarkan data-data di atas maka disimpulkan bahwa hasil belajar peserta didik pada mata pelajaran produktif Teknik Komputer dan Jaringan materi merakit personal komputer yang diajarkan menggunakan media video pembelajaran teruji kebenaranya. Hal ini berarti hasil belajar yang menggunakan media video pembelajaran sebesar 83,66 \% lebih tinggi dari peserta didik yang diajarkan tanpa menggunakan media video pembelajaran dengan efektifitas sebesar $69,46 \%$, perhitungan selengkapnya ada pada lampiran.

Kefektifian media video pembelajaran berbasis pendekatan scientific pada pelajaran biologi dengan materi sistem pertahanan tubuh diperoleh dengan cara sebagai berikut :

$\mathrm{X}=\frac{\text { Jumlah Skor yang diperoleh }}{\text { jumlah skor maksimal }} \times 100 \%$

$X=\frac{2928}{3500} \times 100 \%=83,66 \%$

Nilai keefektifan media video pembelajaran berbasis pendekatan scientific ini lebih tinggi dari nilai kefektifan pembelajaran tanpa media video pembelajaran yaitu sebesar $73,06 \%$ yang diuraikan sebagai berikut :

$\mathrm{X}=\frac{\text { Jumlah Skor yang diperoleh }}{\text { jumlah skor maksimal }} \times 100 \%$

$X=\frac{2431}{3500} \times 100 \%=69,46 \%$

Hal ini berarti hasil belajar peserta didik yang menggunakan media video pembelajaran dengan materi merakit personal komputer lebih tinggi dari hasil belajar peserta didik yang diajar tanpa menggunakan media video pembelajaran pada pelajaran merakit personal komputer sebesar $83,66 \%$ perhitungan selengkapnya pada lampiran. 


\section{Hasil Uji Coba Hipotesis II}

Adapun rangkuman dari hasil uji coba hipotesis II yakni mengenai keefektifan media video pembelajaran rias karakter ini dapat dilihat pada Tabel 9 berikut :

Tabel 9 . Hasil Uji Coba Keefektifan Media Rias Karakter

\begin{tabular}{|c|c|c|}
\hline \multicolumn{2}{|c|}{ Pengujian Media } & \multirow{2}{*}{ Keterangan } \\
\hline Kelas Eksperimen & Kelas Kontrol & Hipotesis diterima \\
\hline $83,66 \%$ & $69,46 \%$ & H \\
\hline
\end{tabular}

Berdasarkan tahapan uji keefektifan produk media video pembelajaran yang telah dipaparkan, maka dapat disimpulkan bahwa media video pembelajaran yang dikembangkan efektif untuk meningkatkan hasil belajar pada materi merakit personal komputer.

\section{Pembahasan Hasil Penelitian}

Pengembangan media video pembelajaran merakit personal komputer dilakukan berdasarkan tahapan sebagaimana yang terdapat dalam prosedur. Hasil pengembangan selanjutnya dilakukan uji kelayakan atau validasi oleh ahli yang telah ditentukan. Berdasarkan hasil validasi yang dilakukan, produk media video pembelajaran merakit personal komputer dinyatakan layak untuk diteruskan dalam uji coba lapangan. Media video pembelajaran merakit personal komputer yang dikembangkan telah memenuhi standar berdasarkan perancangan standar pengembangan media video pembelajaran dan standar materi pembelajaran.

Penelitian pengembangan produk yang dilakukan ini diarahkan untuk menghasilkan suatu produk berupa media video pembelajaran merakit personal komputer yang digunakan untuk meningkatkan proses pembelajaran maupun kompetensi peserta didik.

Aspek yang direvisi dan disempurnakan berdasarkan analisis data dan uji coba serta masukan dari ahli materi, ahli desain pembelajaran, ahli media video pembelajaran ini. Hal ini bertujuan untuk menggali beberapa aspek yang lazim dalam proses pengembangan suatu produk. Variable-variabel media video pembelajarn yang dinilai meliputi kelayakan isi, penyajian, kegrafikan, keaktifan, kebahasaan, pemograman, tampilan dan pemanfaatan.

Pada hasil angket yang disampaikan kepada ahli media video pembelajaran memberikan tanggapan $92,67 \%$ bahwa media video pembelajaran layak digunakan karena telah memenuhi prinsip-prinsip dan criteria pengembangan media video pembelajaran. Sementara itu, ahli desain pembelajaran memberikan tanggapan $93,53 \%$ bahwa media video pembelajaran merakit personal komputer layak digunakan karena telah didesain sedemikian rupa dan memenuhi standar desain pembelajaran. Ahli materi pembelajaran member tanggapan $92,27 \%$ bahwa media video pembelajaranmerakit personal komputer layak digunakan karena telah memuat materi dan criteria penyampaian yang memenuhi syarat penyampaian pesan kepada peserta didik. Berdasarkan analisis hasil nilai rata-rata produktif Teknik Komputer Dan Jaringan yang diajarkan menggunakan media video pembelajaran merakit personal komputer sebesar $83,66 \%$, sedangkan hasil nilai rata-rata mata pelajaran produktif Teknik Komputer Dan Jaringan $69,46 \%$. Dengan melihat pedoman dan kriteria penilaian menurut Sugiono (2010: 257) maka dapat disimpulkan data diatas membuktikan bahwa penggunaan media video pembelajaran merakit personal komputer lebih efektif dalam meningkatkan kompetensi dan pengetahuan peserta didik pada mata pelajaran produktif Teknik Komputer Dan Jaringan pada materi merakit personal komputer.

\section{Pembahasan Hasil Penelitian Uji Coba Kelayakan Produk}

Berdasarkan hasil validasri yang dilakukan, produk media video pembelajaran merakit personal komputer Dan Jaringan dinyatakan layak untuk diteruskan dalam uji coba lapangan. Media video pembelajaran yang dikembangkan telah memenuhi standar berdasarkan perancangan standar pengembangan media video pembelajaran dan standar materi pembelajaran hal ini dapat terlihat pada Tabel 10 di bawah ini : 
Tabel 10. Rangkuman Hasil Kelayakan Produk Berdasarkan Ahli Materi, Ahli Desain, Ahli Media Pembelajaran

\begin{tabular}{|l|l|l|}
\hline \multicolumn{1}{|c|}{ Ahli Validasi } & \multicolumn{1}{c|}{ Hasil Persentase } & \multicolumn{1}{c|}{ Layak / Tidak Layak } \\
\hline Ahli Materi Pembelajaran & $92,27 \%$ & Layak digunakan \\
\hline Ahli media Pembelajaran & $92,67 \%$ & Layak digunakan \\
\hline Ahli desain Pembelajaran & $93,53 \%$ & Layak digunakan \\
\hline
\end{tabular}

Pada hasil angket yang disampaikan kepada ahli media video pembelajaran memberikan tanggapan $92,67 \%$ bahwa media video pembelajaran layak digunakan karena telah memenuhi prinsip-prinsip dan criteria pengembangan media video pembelajaran. Sementara itu, ahli desain pembelajaran memberikan tanggapan $93,53 \%$ bahwa media video pembelajaran merakit personal komputer layak digunakan karena telah didesain sedemikian rupa dan memenuhi standar desain pembelajaran. Ahli materi pembelajaran memberikan tanggapan $92,27 \%$ bahwa media video pembelajaran pembelajaran tutorial merakit personal komputer layak digunakan karena telah memuat materi dan criteria penyampaian yang memenuhi syarat penyampaian pesan kepada peserta didik.

\section{Pembahasan Hasil Penelitian Uji Keefektifian Produk}

Dari hasil pengolahan data penelitian yang dilakukan, terdapat rata-rata hasil belajar produktif Teknik Komputer Dan Jaringan yang dibelajarkan menggunakan media video pembelajaran merakit personal komputer pada siswa kelas X Teknik Komputer Dan Jaringan yaitu sebesar 83,66\%. Sedangkah hasil belajar produtf Teknik Komputer Dan Jaringan materi merakit personal komputer diajarkan tanpa menggunakan media video pembelajaran sebesar $69,46 \%$. Dari data ini membuktikan bahwa media video pembelajaran merakit personal komputer pada siswa kelas X Teknik Komputer Dan Jaringan ini layak dan efektif digunakan dalam meningkatkan kompetensi dan pengetahuan peserta didik.

Penggunaan media video pembelajaran merakit personal komputer memungkinkan peserta didik untuk lebih mudah memahami langkah-langkah merakit komputer karena dari media video pembelajaran ini memungkinkan peserta didik untuk berinteraksi langsung, memiliki susunan tahapan pembelajarang yang lebih teratur dan lebih jelas, sehingga setiap peserta didik tidak kesulitan lagi dalam memecahkan masalah. Selain itu media video pembelajaran ini sangat praktis, karena media ini dapat dibawa peserta didik dan dipelajari di rumah.

\section{PENUTUP}

Berdasarkan hasil dan pembahasan penelitian pengembangan media video pembelajaran yang dilakukan maka dapat disimpulkan sebagai berikut :

1. Hasil validasi dari ahli materi terhadap media video pembelajaran tutorial merakit personal komputer yang dikembangkan menunjukkan bahwa : (1) kelayakan isi materi pembelajaran dinilai dengan sangat baik dengan persentase rata-rata $92,00 \%$, (2) kelayakan penyajian dinilai sangat baik dengan persentase rata-rata $93,75 \%$, (3) kelayakan kebahasaan dinilai dengan sangat baik dengan persentase 93,33\%, (4) kelayakan pada aspek kegrafikan dinilai dengan sangat baik dengan skor persentase $90,00 \%$, sehingga kesimpulannya hasil validasi dari ahli materi terhadap media video pembelajaran yang dikembangkan skor rata-rata persentasenya dalam kriteria sangat baik dengan skor 92,27\%. Hasil validasi ahli desain pembelajaran terhadap media video pembelajaran berbasis pendekatan scientific yang dikembangkan adalah (1) aspek kelayakan isi desain pembelajaran dinilai sangat baik dengan persentase rata-rata sebesar $95,00 \%$, (2) aspek penyajian kualitas desain pembelajaran dinilai sangat baik dengan persentase rata-rata sebesar $92,73 \%$, (3) pada aspek kebahasaan dinilai sangat baik dengan persentase rata-rata sebesar $92,86 \%$, dengan demikian hasil validasi ahli desain pembelajaran tersebut disimpulkan dalam kriteria sangat baik $(93,53 \%)$.

2. Hasil validasi materi video pembelajaran terhadap media video pembelajaran tutorial merakit personal komputer yang dikembangkan menunjukkan bahwa : (1) pada aspek pemrograman dinilai sangat baik dengan persentase sebesar 92,00\%, (2) pada aspek kualitas teks dan tampilan dinilai sangat baik dengan persentase 
sebesar 93,33\%. Berdasarkan hasil validasi tersebut disimpulkan bahwa materi video pembelajaran tutorial merakit personal komputer yang dikembangkan dalam kriteria sangat baik $(92,27 \%)$, sehingga dapat diterima dan layak digunakan dalam proses pembelajaran.

\section{DAFTAR PUSTAKA}

AECT. (1977). Definisi Teknologi Pendidikan (satuan tugas definisi \& terminology $A E C T$ ). Jakarta: Rajawali

Agus Saputra, (2011), Trik dan Solusi Jitu Pemrograman PHP, PT. Elex Media Komputindo, Jakarta

Ahmadi dan Supriyono. (2008). Psikologi Belajar. Jakarta: PT. Rineka Cipta.

Anglin, Gary J. (1995). Instruksional Technology. Englewood, Colo, Libraries Unlimited

Azhar. (2014) . Media Pembelajaran ( Edisi Revisi ). Jakarta : PT Raja Grafindo Persada.

Borg,W.R \& M.D.Gall.(1983). Educational Research: An Introduction, New York: Longman, Inc.

Daryanto. 2011. Media Pembelajaran. Yogyakarta: PT. Gava Media.

Dick, Walter, etc.(2001). The Systematic Design of Instruction. Fifth Edition.Wesley Educational Publishers Inc..

Gagne E.D. (1985). The Cognitive Psychology of School Learning. Boston : Little Brown

Hackbarth, S. (1996). The Educational Technology Hand-book A Comprehensive Guide Process and Products For Learning. New Jersey: Educati-onal Technology Publications

Hamalik, Oemar. (2005). Proses Belajar Mengajar, Bandung: Bumi Aksara.

Hamalik, Oemar. 2002. Media Pendidikan. Bandung: PT Aditya Bakti.

Komaruddin, Hidayat. (2000). Active Learning. Yogyakarta. Yappendis
Kunandar. (2010). Langkah Mudah Penelitian Tindakan Kelas Sebagai Pengembangan Profesi Guru. Rajawali. Jakarta.

Miarso, Yusufhadi. (2004). Menyemai Benih Teknologi Pendidikan. Jakarta: Prenada Media dan Pustekkom Diknas.

Musfiqon,HM. (2012).Pengembangan Media dan Sumber Pembelajaran. Jakarta: Prestasi Pustaka Karya.

Reigeluth, M Charles. (1983). Instructional-Design Theories and Models, An Overview of their Current Status. New jersey: London.

Rusman, (2012). Belajar dan Pembelajaran Berbasis Komputer. Alfabeta. Bandung.

Sadiman, Arif dkk. (2002). Media Pendidikan: Pengertian, Pengembangan dan Pemanfaatannya. Jakarta: Raja Grafindo Persada.

Sahid, (2010), Pengembangan Media Pembelajaran berbsis ICT(Information communication and Technology), UNY

Sanaky, A.H Hujair. (2009). Media Pembelajaran, Yogyakarta: Safiria Insania Press.

Seels, Barbara B. Richey, Rita C. (1994) Teknologi Pembelajaran: definisi dan kawasannya. Penerjemah Dewi S. Prawiradilaga dkk. Jakarta: Kerjasama IPTPI LPTK UNJ

Smaldino,S.E dkk. (2008). Instructional Technology and Media For Learning.Jakarta: Kencana Prenada Media Group.

Smith, P. L. \& Ragan, T. J. .(1993). I nstructional desig $\mathrm{n}$. New York: Macmillan Publishing Company.

Sudjana, Nana. (2009). Penilaian Hasil Proses Belajar Mengajar. Remaja Rosda Karya. Bandung.

Sugiyono. (2014). Metode Penelitian Kuantitatif, Kualitatif, dan Kombinasi (Mixed Methods). Bandung: Alfabeta.

Suparman, Atwi. (2011), Desain Intruksional Modern. Jakarta: Penerbit Erlangga 